\title{
USE OF GIS AND REMOTE SENSING TO DETECT CHANGE ALONG THE COASTLINE SEGMENT BETWEEN SHKUMBINI AND SEMANI RIVERS, CENTRAL ALBANIA
}

\author{
Bedini E. \\ ${ }^{1}$ Geological Survey of Albania, Blloku 'Vasil Shanto', Tirana, Albania, bedini07607@itc.nl
}

\begin{abstract}
The coastline segment between Shkumbini and Semani rivers, in central Albania, is a very dynamic accumulative coastal environment. The position of the coastline in this segment is investigated with multi-temporal Landsat data of the years 19782001 integrated in a geographic information system. The analysis of the multitemporal remote sensing data shows that the coastline of this segment is subject to important changes during this short time interval. The study demonstrates the applicability and usefulness of historical Landsat data for change detection studies of the coastal environment.
\end{abstract}

Key words: Landsat imagery, Semani River delta, coastal erosion.

\section{Пврі́^пчи}

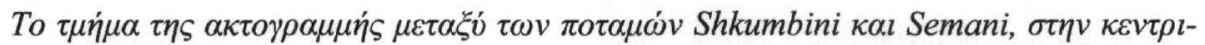

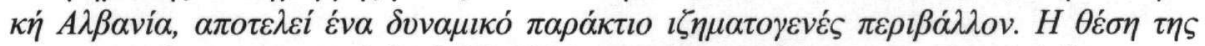

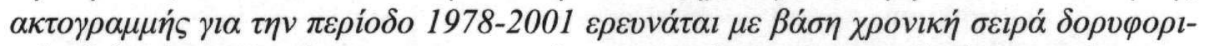

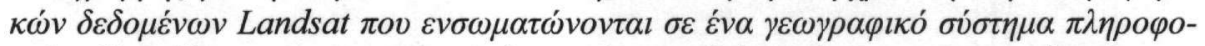

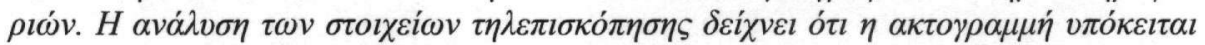

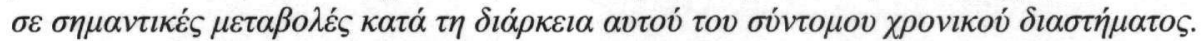

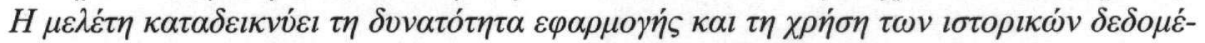

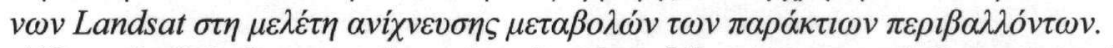

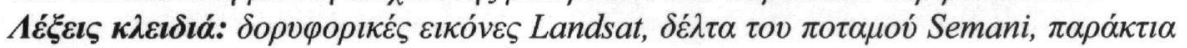
$\delta ı \dot{\alpha} \beta \rho \omega \sigma \eta$.

\section{Introduction}

Change detection is the process of identifying differences in the state of an object or phenomenon by observing it at different times (Singh 1989). Timely and accurate change detection of Earth's surface features provides the foundation for better understanding relationships and interactions between human and natural phenomena to better manage and use resources (Lu et al. 2003). In general, change detection involves the application of multi-temporal datasets to quantitatively analyse the temporal effects of the phenomenon ( $\mathrm{Lu}$ et al. 2003). Remote sensing data are an important source of information for change detection studies.

Continental and oceanic processes converge along the coast to create landscapes typical of rapid change (Keller 1996). The low Adriatic Coast of Albania (about $230 \mathrm{~km}$ from the Buna River mouth to Vlora bay) is distinguished for its strong dynamics expressed by the large accumulation 
and seaward advancement of the coastline in several sectors and by the strong and rapid erosion and advancement of the sea in the mainland in several other sectors (Kabo 1990). These opposite processes lead to large and rapid changes of the coastline configuration.

This study investigates through multi-temporal Landsat imagery of the years 1978, 1981, 1989, 2001 the changes that have occurred during this time interval in the coastline sector from Shkumbini River mouth to Semani River mouth, in central Albania (Fig. 1). Despite the short time interval, the presence of a very dynamic coastline in this sector has led to significant changes. For the analysis of the multi-temporal remote sensing data we used a GIS technique.

\section{Study area}

The coastline segment between Shkumbini and Semani river mouths in the Myzeqe plain in central Albania, is part of the low-lying Adriatic coastline of Albania (Fig.1). This coastline is characterized by a very active sedimentary regime with considerable coastline changes that take place over time scales of a few decades (Kabo 1990).

Quaternary deposits and Pliocene molasses crop out in the surface (Fig. 1). The Pliocene molasses build up a range of hills along the so-called Ardenica-Divjaka-Ballaj anticline. They consist of conglomerates, clays, silts and sandstones (Vranai et al. 1997). Alluvial, marine and marsh formations make up the quaternary deposits. They consist of sands, clays, turfs, gravels. The Karavasta Lagoon is the most striking geomorphological feature of the area. It has an area of 4100 ha, the maximum depth is $1.3 \mathrm{~m}$ and the average depth $0.7 \mathrm{~m}$ (Kabo 1990).

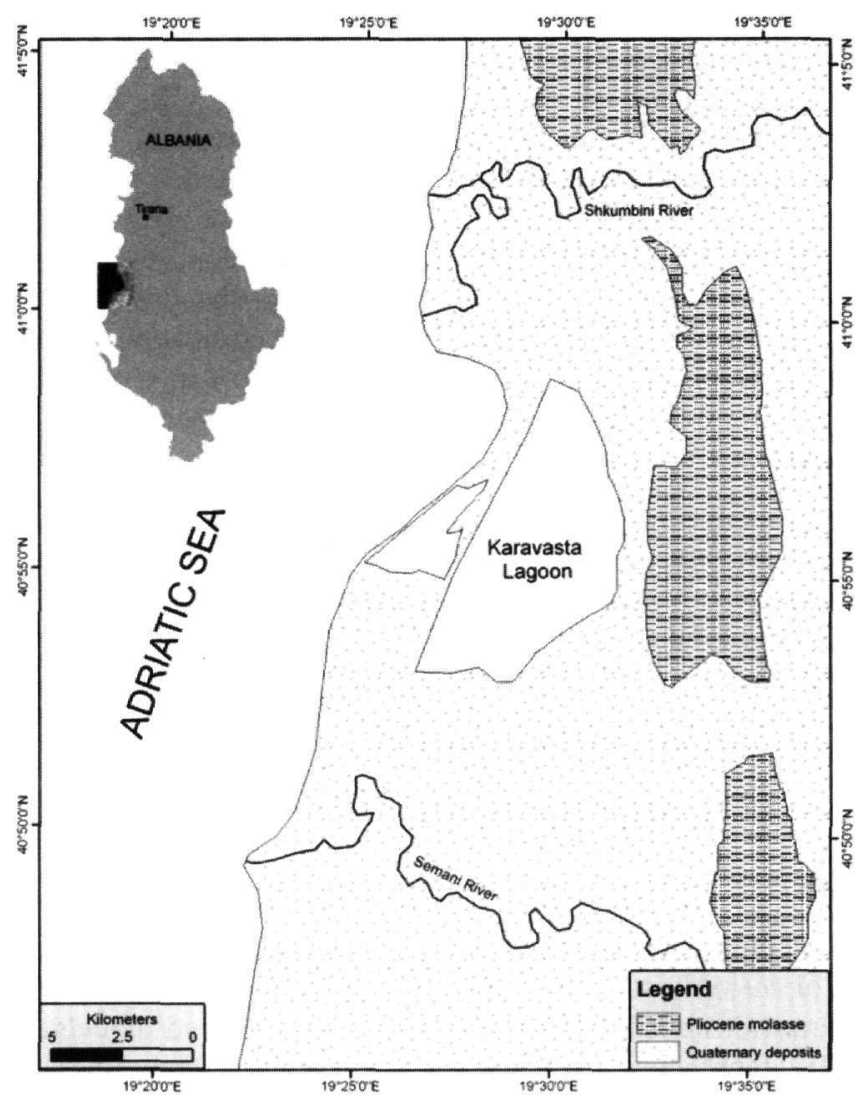

Figure 1 - Schematic geological map of the Karavasta area in central Albania. The position of the coastline is based on Landsat data of 2001 
The quaternary geology and coastal morphology of this region is shaped from the activity of Shkumbini and Semani rivers. These rivers have high water discharge and sedimentary load (Table 1). The rivers have often changed their river mouth position in search for equilibrium in the coastal plain (Pano 1992, Kabo 1990). The Semani river has changed the position of its mouth at least six times in the last 100 years along a corridor $25 \mathrm{~km}$ long (Boçi 1994, Ciavola et al. 1999). The shift toward the south of the Semani River mouth at the beginning of the 70 -ies led to an erosive situation at the abandoned delta of the river, as the input of sedimentary material ceased. A part of the sediment eroded from the abandoned delta was transported northward forming a belt of sand that formed the Godulla lagoon. However, this sand belt is also subject to erosion which may lead to the destruction of the Godulla lagoon (Technital 1995). Shkumbini River moved its main outlet some $4 \mathrm{~km}$ in the north of the previous one in 1996.

Table 1 - Catchment area, mean annual water discharges and sediment load of Shkumbini and Semani rivers (after Pano 1992)

\begin{tabular}{|l|c|c|c|}
\hline River & Catchment $\left(\mathbf{k m}^{2}\right)$ & Discharge $\left(\mathbf{m}^{3} / \mathbf{s}\right)$ & $\begin{array}{c}\text { Sediment discharge } \\
\text { (tons/year) }\end{array}$ \\
\hline Shkumbini & 2444 & 61.5 & $7.2 \times 10^{6}$ \\
\hline Semani & 5649 & 95.7 & $16.5 \times 10^{6}$ \\
\hline
\end{tabular}

\section{Landsat imagery}

The Landsat series of earth observation satellites (Landsat MSS, Landsat TM, Landsat ETM+) provide a unique historical dataset for change detection studies. The Landsat MSS is no longer operational, though a substantial archive of imagery remains available (Mather 2004). The MSS was a four-band instrument, with two visible channels in the green and red wavebands, respectively and two near-infrared channels $(0.5-0.6 \mu \mathrm{m}, 0.6-0.7 \mu \mathrm{m}, 0.7-0.8 \mu \mathrm{m}, 0.8-0.11 \mu \mathrm{m})$. Landsat MSS has a swath width of $185 \mathrm{~km}$ and pixel size of $79 \mathrm{~m}$ (along track) x $57 \mathrm{~m}$ (across track), (Mather, 2004). The TM and ETM+ have seven spectral bands that cover the visible, near infrared, short-wave infrared and thermal infrared regions of the electromagnetic spectrum. Pixel size is $28.5 \times 28.5 \mathrm{~m}$ with the exception of the thermal infrared band that has lower spatial resolutions. The Landsat ETM+ has an additional $15 \mathrm{~m}$ spatial resolution panchromatic band. Currently (November, 2006) only Landsat TM is operational.

In this study to detect change in the coastline segment between Shkumbini and Semani river mouths were used four Landsat scenes that were made available from the Global Land Cover Facility (GLCF) of the Maryland University, USA. These Landsat scenes are part of the NASA's global orthorectified Landsat data set (see Tucker et al. 2004). The first scene was recorded by the Landsat MSS on September 16, 1978; the second scene was recorded by the Landsat MSS on August 3, 1981. The third scene was recorded by Landsat TM (Landsat 5) multispectral scanner on July 22, 1989, whereas the fourth scene was recorded by the Landsat ETM+ multispectral scanner (Landsat 7) on October 3, 2001. Grey scale images of the Landsat scenes are shown in (Fig. 2).

\section{Data analysis}

A variety of change detection techniques have been developed (see Lu et al. 2003 for a thorough review). For the sake of convenience, the change detection methods are grouped into seven categories: (1) algebra, (2) transformation, (3) classification, (4) advanced models, (5) Geographical Information System (GIS) approaches, (6) visual analysis, and (7) other approaches (Lu et al. 2003). Due to the different spatial and spectral resolution of the Landsat MSS scenes with the Landsat 
TM and ETM+ scenes a GIS and visual analysis approach was applied to detect changes along the coastline segment between Shkumbini and Semani Rivers for the 23 year period 1978-2001.

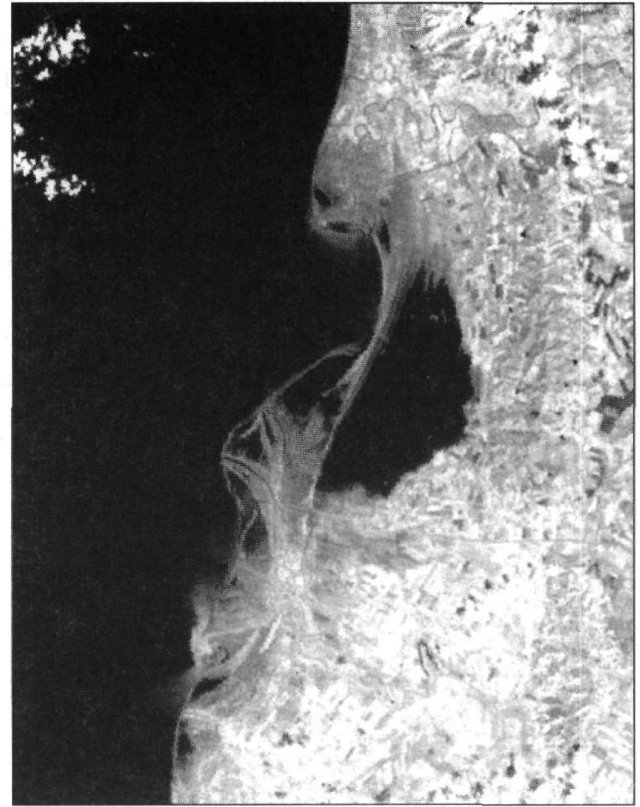

Landsat MSS 1978

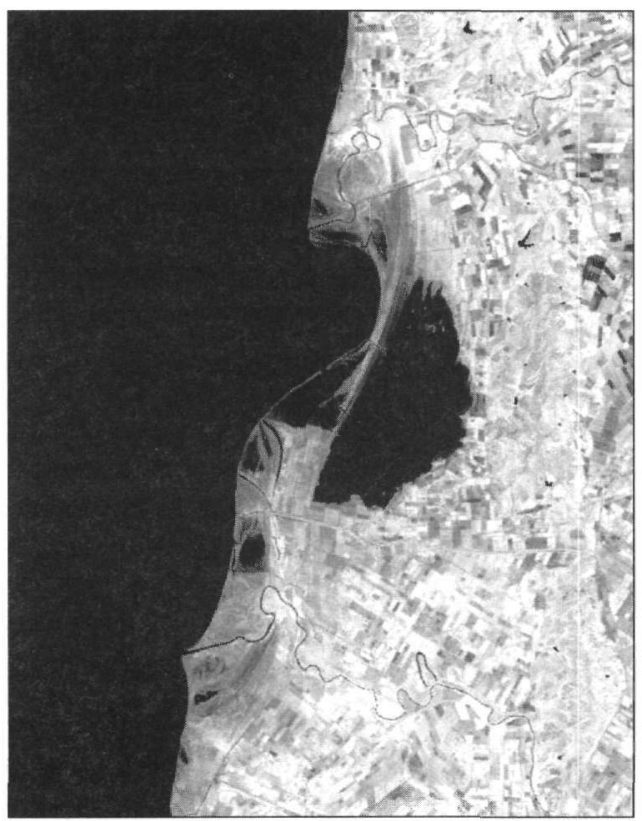

Landsat TM 1989

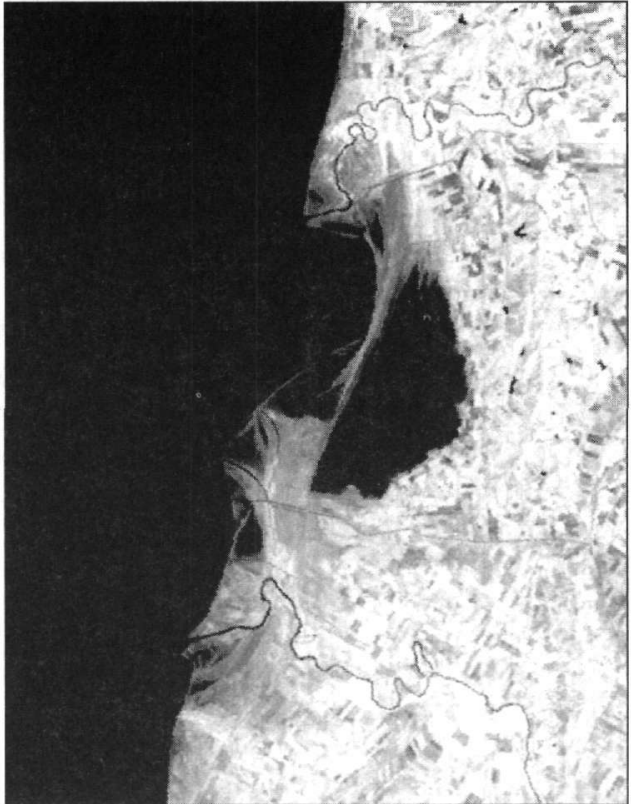

Landsat MSS 1981

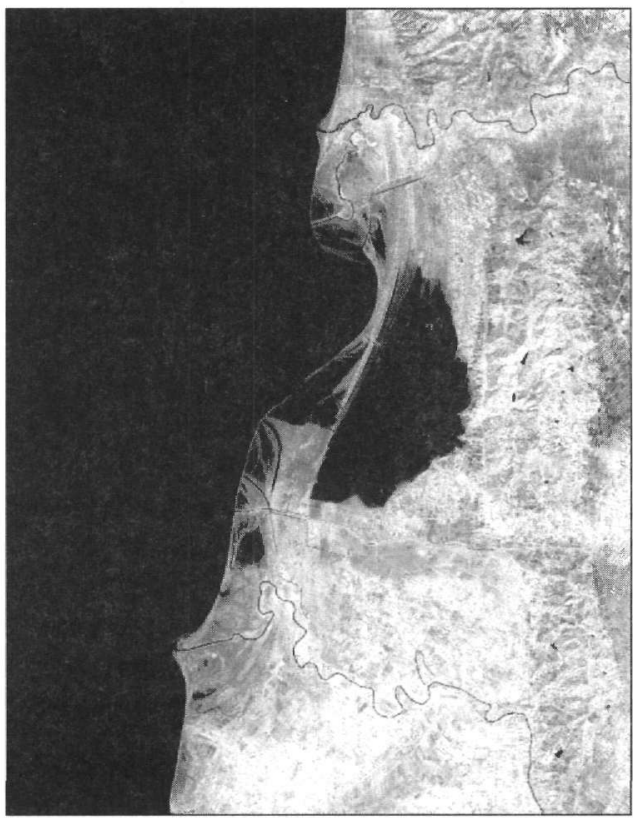

Landsat $\mathrm{ETM}+2001$

Figure 2 - Grey scale images of the Landsat MSS 1978 (band 3), Landsat MSS 1981 (bands 4), and of the Landsat TM and ETM+ of 1989 and 2001 (band 4) over the Shkumbini River mouth

- Semani River mouth coastal segment, Albania. Images cover an area of $37 \times 28.5 \mathrm{~km}$

The reported positional accuracy of the NASA's orthorectified global Landsat dataset has a rootmean-square error of less than 50 metres for the Landsat TM/ETM+ and a root-mean-square error 
of less than 100 metres for the Landsat MSS (Tucker et al. 2004). Due to the fact that the area of this study is flat higher positional accuracy is expected. The excellent geodetic accuracy of the NASA's orthorectified Landsat data saves substantial time by avoiding extensive coregistration among the Landsat data of the three epochs 1970s, circa 1990, and circa 2000 (Tucker et al. 2004). The Landsat MSS scenes were resampled to the spatial resolution of the Landsat TM/ETM+ imagery. Images were coregistered with each other. The registration error was $15 \mathrm{~m}$ in the registration of TM/ETM+ and $40 \mathrm{~m}$ in the registration among Landsat MSS/TM.

The accuracy of the change detection measured digitally using TM/ETM+ data is $\pm 40 \mathrm{~m}$, and \pm 113 $\mathrm{m}$ when using MSS/TM or MSS/MSS data assuming perfect coregistration. This is determined from the following formula (Williams et al. 1997, quoted in Hall et al. 2003): Uncertainty = $\operatorname{sqrt}\left(28.5^{2}+28.5^{2}\right)$ for the $28.5-\mathrm{m}$ resolution TM or ETM+ data. Including also the registration error gives accuracy of $\pm 55 \mathrm{~m}$ for the TM/ETM+ change detection and of $\pm 153 \mathrm{~m}$ when Landsat MSS images are used in the change detection. This approach of reporting uncertainty is similar to (Hall et al. 2003). However, error is induced also from the digitization and uncertainty in feature boundary location in the GIS and visual analysis of the landscape change (Crowell et al. 1991, Zviely and Klein 2004, Levin 2006).

Using ILWIS (van Westen and Farifteh 1997) and ArcGIS 9.0 GIS platforms all the images were integrated in a Geographic Information System (GIS). The coastline position was digitized on screen from each of the images and from colour composites which combined images of different years as RGB. Results are shown in Figure. 3.

\section{Results}

This simple GIS and visual analysis approach of such a large segment of the Albanian coastline shows that many changes have occurred during this twenty-three year time interval. The most striking change of the coastline is the strong erosion of the abandoned delta of Semani River (Fig. 3). Mainland has rather advanced toward the sea north of the Semani delta, probably due to sedimentary material moved from the eroded delta.

The change of the river mouth position of Shkumbini river in 1995 is associated with the immediate formation of a new delta, whereas in the former active river mouth of Shkumbini river, the sedimentary material has moved toward the south (Figure. 3). Semani river has also created its new delta.

One of the objectives of change detection studies is to measure the degree of change and if possible the rate of change (Lu et al. 2003). Below we focus on the degree of change and try to quantify the rate of change in the case of the erosion of the former Semani river delta. A detailed view of the areas eroded and accreted at the abandoned delta of Semani River and the nearby areas is shown in (Fig. 4). Results of Landsat image analysis for this area (shown in Fig. 4) indicate that approximately 500 ha of land has been eroded and 112 ha of land has been created mainly due to the sedimentation of the material removed from the abandoned delta of Semani river. Between 1989 and 2001 the erosive situation has practically destroyed the sand spit of the Godulla lagoon. This was predicted earlier from a report of (Technital 1995).

The rate of erosion of Semani delta has not been uniform during this time interval. Along the axis of the sub-aerial part of the eroded delta (with a length of about 1300 m), (Fig. 4) between 19781981 the sea advanced for about $450 \mathrm{~m}$ (with a rate of $150 \mathrm{~m} /$ year), between 1981-1989 the sea advanced for about $430 \mathrm{~m}$ (a rate of more than $50 \mathrm{~m} /$ year) and between 1989-2001 the sea advanced for about $420 \mathrm{~m}$ (a rate of $35 \mathrm{~m} /$ year). 


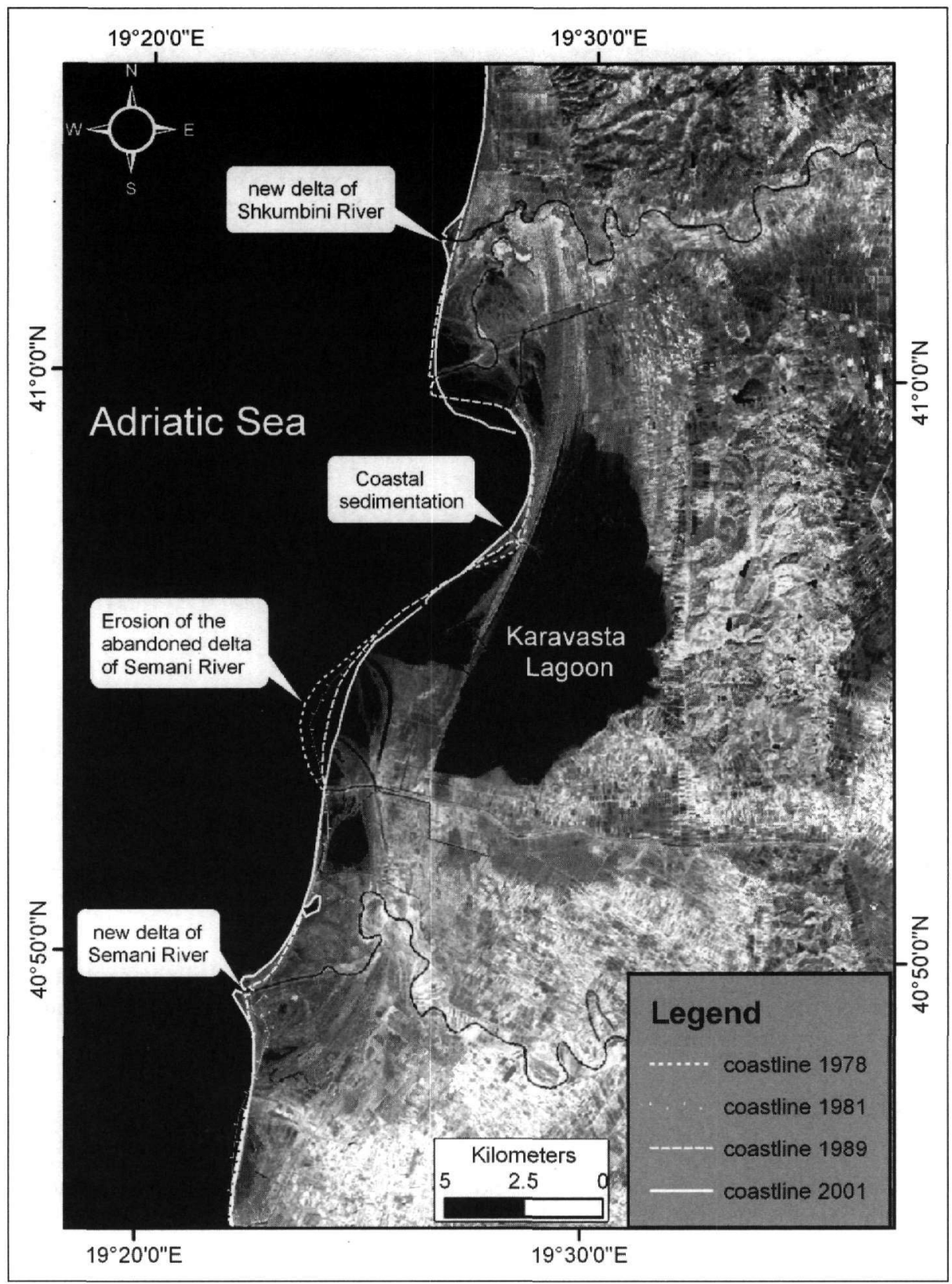

Figure 3 - The position of the coastline in the coastal segment between Semani and Shkumbini rivers, central Albania, in the 1978-2001 time interval. Coastline digitized on screen from Landsat data of the years $1978,1981,1989,2001$. The background is band $4(0.75-0.90$ $\mu \mathrm{m})$ of the Landsat ETM+ scene of 2001

It is to be noted that these rates of change for the time gap between the images are far above the error range of $\pm 55 \mathrm{~m}$ when using Landsat $\mathrm{TM} / \mathrm{ETM}+$ data and $\pm 153 \mathrm{~m}$ when using Landsat MSS/TM data in the change detection. However the error range requires a minimum time gap between the images. For example if TM/ETM+ images of the 1990-2000 time interval are used to detect the rate of the land erosion at the abandoned Semani delta, in order to extract statistically significant results (where data reliability exceeds the margin of error) the minimum time gap between the two images should be at least 3 years. 


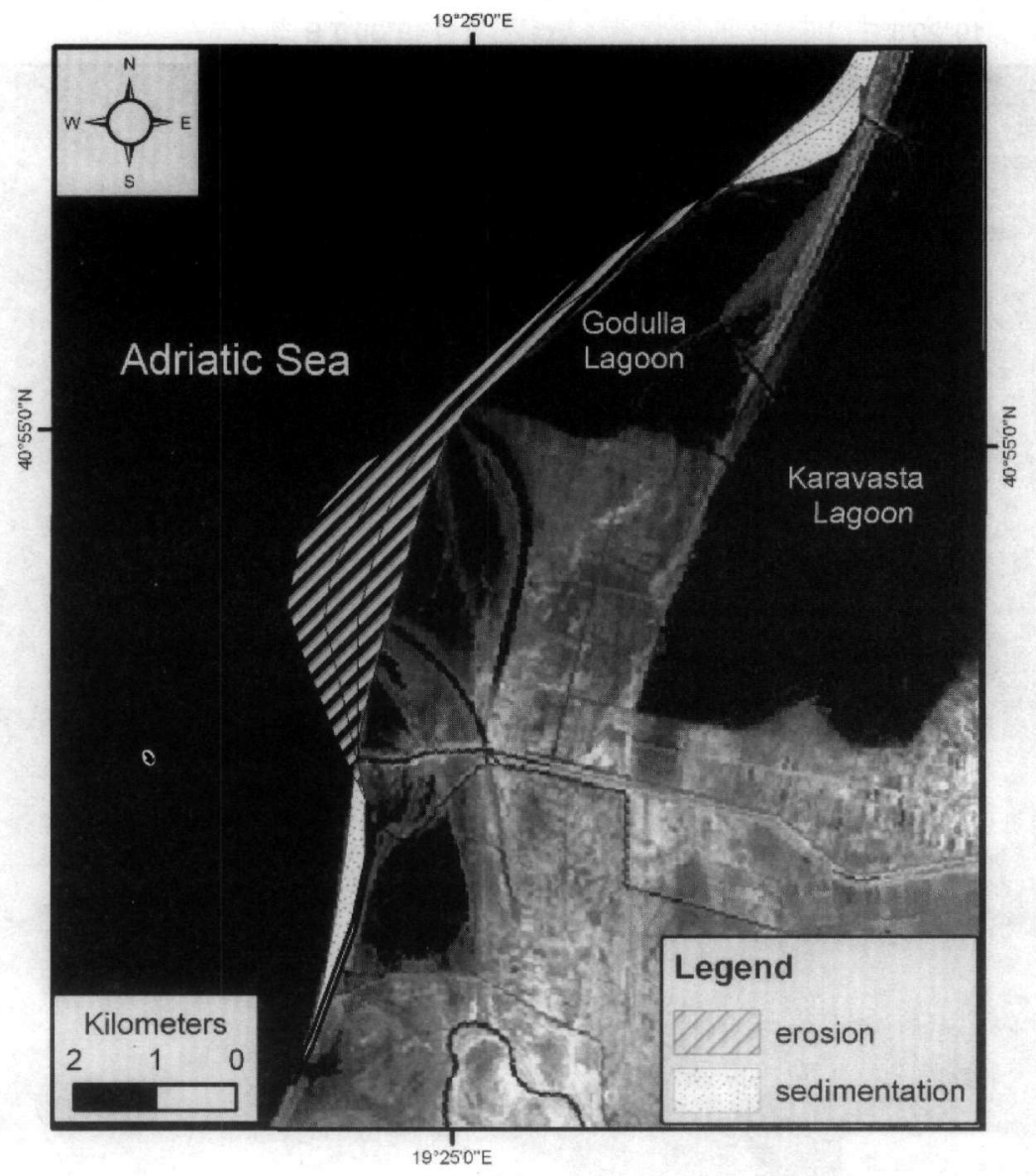

Figure 4 - Erosion and sedimentation at the abandoned delta of Semani river and the nearby area between the years 1978-2001 based on the analysis of Landsat imagery. The background is band $4(0.75-0.90 \mu \mathrm{m})$ of the Landsat scene of 2001

\section{Conclusions}

Integrating remotely sensed data acquired by the Landsat earth observing satellite in a geographic information system (GIS) we investigated the position of the coastline in the coastal segment between Shkumbini and Semani river mouths, in central Albania, for a twenty-three year period (1978-2001). This segment of the Albanian coast is the most dynamic of the accumulative coast of Albania due to the activity of the Shkumbini and Semani rivers, distinguished for their high water discharge and sedimentary load.

Important changes have occurred along this coastline segment during this time interval. The most important change is related to the erosion of the abandoned delta of the Semani river. While since the mid of the year ' 70 the Semani river has changed its river mouth position south of the previous one, the abandoned delta is being eroded as it is in disequilibrium while no more sedimentary material is reaching to it. The surface of the eroded land from the abandoned delta of Semani river mounts to over 500 ha. Coastal sedimentation has taken place in the south and in the north of the eroded delta and a land surface of about 120 ha has been created. As predicted from earlier studies (Technital 1995) the sand spit which formed the Godulla lagoon in the first steps of the erosion of Semani delta is now being eroded also. This will lead to the destruction of the Godulla Lagoon. 
Other important changes are to be noted in the river mouth of Shkumbini River. The river has established a new main river mouth (since 1996) north of the existing one. At the new river mouth a delta formed rapidly. The former river mouth is being eroded but the sedimentary material seems to have sedimented south of the former main delta of Shkumbini. In the same way Semani river has established its new delta.

The study demonstrates the applicability and the importance of historical Landsat data for coastline change detection, especially along the Albanian very dynamic accumulative coastline. Integration of aerial photography with satellite data and the use of imagery from other satellites (e.g. ASTER) would make possible applications with better temporal and spatial resolutions in the future.

\section{Acknowledgment}

The author is indebted to Dr. Petraq Naço (Geological Research Institute, Tirana) for his discussions on the geology, geomorphology and change of the coastline of the study area. An anonymous reviewer is cordially thanked for his valuable comments on the content of the paper.

\section{References}

Boçi, S., 1994. Evoluzione e problematiche ambientali del litorale albanese, Bolletino Societa Geologica Italiana, 113, 7-14.

Ciavola, P., Mantovani, F., Simeoni, U., and Tessari, 1999. Relation between river dynamics and coastal changes in Albania: an assessment integrating satellite imagery with historical data, Interantional Journal of Remote Sensing, 20(3), 561-584.

Crowell, M., Leatherman, S.P., and Buckley, M.K., 1991. Historical shoreline change: Error analysis and mapping accuracy, Journal of Coastal Research, 7 (3), 839-852.

Hall, D.K., Bayr, K.J., Schöner, W., Bindschadler, R.A., and Chien, J.Y.L., 2003. Considerations of the errors inherent in mapping historical glacier positions in Austria from the ground and space (1893-2001), Remote Sensing of Environment, 86, 566-577.

Kabo, M., (ed.), 1990. Gjeografia Fizike e Shqipërisë. Pjesa e Parë. Qendra e Studimeve Gjeografike, Tirana, Albania.

Keller, E., 1996. Environmental Geology, Seventh Edition. Prentice Hall. 560pp.

Levin, N., 2006. The Palestine Exploration Fund Map (1871-1877) of the Holy Land as a Tool for Analysing Landscape Changes: The Coastal Dunes of Israel as a Case Study, The Cartographic Journal, 43(1), 45-67.

Lu, D., Mausel, P., Brondizios, E., and Moran, E., 2003. Change detection techniques, International Journal of Remote Sensing, 25(12), 2365-2407.

Mather, P., 2004. Computer processing of remotely sensed images, Third edition. 324 p. John Wiley \& Sons, Ltd.

Pano, N., 1992. Dinamica del litorale Albanese - sintese delle conoscense, Atti del diciannovesimo convegno AIGI, 3-18pp.

Singh, A., 1989. Digital change detection techniques using remotely sensed data, International Journal of Remote Sensing, 10, 989-1003.

Technital, 1995. Study on the hydro-biological importance of the lagoon channels. European Commission, PHARE program: Karavasta lagoon wetland management project, Technital S.p.A., Venezia, 69pp. 
Tucker, C.J., Grant, D.M., and Dykstra, J.D., 2004. NASA's Global Orthorectified Landsat Data Set, Photogrammetric Engineering \& Remote Sensing, 70(3), 313-322.

Van Westen, C., and Farifteh, J., 1997. The ILWIS 2.1 for Windows User's Guide, Enschede, ILWIS Department, International Institute for Aerospace Survey and Earth Sciences ITC, $511 \mathrm{pp}$.

Vranai, A., Shallo, M., and Xhomo, A., 1997. Geology of Albania. Tirana, Albania. 394pp. (in Albanian)

Williams, R.S. Jr., Hall, D.K., Sigurdsson, O., and Chien, J.Y.L., 1997. Comparison of satellitederived with ground based measurements of the fluctuations of the margins of Vatnajökull, Iceland, 1973-1992. Annals of Glaciology, 24, 72-80.

Zviely, D., and Klein, M., 2004. Coastal cliff retreat rates at Beit-Yannay, Israel in the 20-th century, Earth Surface Processes and Landforms, 29, 175-184. 